6092

Research Article

Journal of Extension Education

Vol. 30 No. 3, 2018

DOI:https://doi.org/10.26725/JEE.2018.3.30.6092-6099

\title{
Determinants of Rural Women's Participation in Agricultural Extension Services: Case of Irrigable Vegetable Production in Oromia Region, Ethiopia
}

\author{
Mulutena Sitachew ${ }^{1}$, J. Paul Mansingh² \& Mulu Debela ${ }^{3}$
}

\begin{abstract}
Women rarely participate in extension services and have little contact with extension service organizations. Increasing extension service to female farmers in rural areas of Ethiopia remains challenging. Reports say that there is low participation of women vegetable farmers in agricultural extension services in Toke-Kutayedistrict, Oromia region, Ethiopia.Therefore, this study seeks to assess the factors influencing rural women participation in agricultural extension services employing both qualitative and quantitative approaches. Out of the 132 women vegetable producers selected for this study, there were 79 participants and 53 non-participants of agricultural extension services. Quantitative data from primary sources were collected using a semi-structured interview schedule. Qualitative data were collected through key informant interviews and focus group discussions.The results of the Binary Logit regression model estimate indicate that out of the 16 explanatory variables included in the model, farming experience, sex of development agent, irrigable land holding size and access to credit shows significant and positive relation with participation whereas, time spent on domestic activities, distance from water source, mobility constraints and sex of household headship shows significant and negative relationship with women participation.
\end{abstract}

Keywords: Rural Women's Participation; Vegetable Cultivation; Agricultural Extension Services; Ethiopia

\section{INTRODUCTION}

Rural women are intimately involved in all aspects of agricultural production than men. A study conducted by Cohen \& Lemma (2011) explains that it takes a short time observation for someone in rural Ethiopia to recognize that women in most parts of the country are deeply involved in every aspect of agricultural activity, such as land preparation, hoeing, weeding, harvesting, threshing, transportation and usage.

However, women rarely participate in extension services and have little contact with extension service organizations. Global surveys show that women receive only five per cent of the total extension resources all over the world dedicated to programmes for female farmers. Women form just 15 per cent

1. Post-Graduate Scholar, 2. Professor, and 3. Assistant Professor Department of Rural Development and Agricultural Extension, Ambo University, Ambo, Ethiopia.

Received : 12-04-2018; Accepted : 12-10-2018 
Determinants of Rural Women's Participation in Agricultural Extension Services: Case of Irrigable Vegetable Production in Oromia Region, Ethiopia

of extension personnel in the world and their roles also remain largely unrecognized and have been virtually ignored by agricultural intervention programmes (World Bank,2010).

In Ethiopia, in general and women vegetable producers in the study area in particular have limited participation in agricultural extension services (Quisumbing et al., 2014). That is why, traditionally women are not considered as "farmers", a predominant problem in many developing countries (World Bank, 2010; Cohen \& Lemma, 2011). Even if females do participate in extension services, they may not be given equal recognition for their responsibilities and skills. They are also restricted and marginalized in terms of providing equal responsibilities, decision making power $\&$ access and control over resources. This is because farmers and farming activities continue to be perceived as "male" by planners and agricultural service deliverers, thereby ignoring the important and increasing role females play in agriculture. Moreover, technology packages delivered by extension services sometimes reinforce stereotypic divisions of labour (Manfre et al., 2013). Recent reports suggest (TKDARDO, 2016) that there is low participation of women vegetable farmers in agricultural extension services in Toke-Kutaye woreda, Oromia region, Ethiopia.

Therefore, this study was carried out to assess the factors influencing rural women participation in agricultural extension services in case of irrigable vegetable production in Toke-Kutay district. This will help facilitate the development of evidence-based polices for increasing the participation of women farmers in the agricultural extension services.

\section{METHODOLOGY}

The study was conducted in TokeKutaye district which is $122 \mathrm{~km}$ away from Addis Ababa, the capital of Ethiopia. This research employed both qualitative and quantitative approaches and adopted cross-sectional survey research design. The population includes all the rural women in the selected kebele ${ }^{1}$, who are actively involved in irrigable vegetable farming in Toke-Kutaye district in the years of 2016 and 2017 farming season. The study employed both purposive and stratified random sampling techniques.

Toke-Kutaye district was selected purposively because, this district is a model district for vegetable production and it has greater potential for vegetable production. Among the 24 rural kebeles in the district, 18 of them are included for irrigable vegetable production scheme (TKADOI, 2016). Then, out of the 18 kebeles, three rural kebeles namely Birbirsa-Duguma, Emela-Dawe and Marufwere were selected purposively, because, these three kebeles are well known for their irrigation potential with high water recourse.

The population was stratified based on the participation in agricultural extension services, as participants and nonparticipants. Out of 132 women vegetable producers selected for this study, there were 79 participants and 53 non-participants of agricultural extension services. Simple

${ }^{1} \mathrm{~A}$ kebele is the smallest administrative unit of Ethiopia, similar to a revenue village. 
random sampling technique was used to select participants and non-participants from the list available with the development agents in the three rural kebeles. Probability proportion to size technique was used to determine the sample size from each selected kebele.

The details of the selected household heads are presented in Table 1.

Table1.

Details of Household Heads (HHs)

\begin{tabular}{|c|c|c|c|c|c|c|c|}
\hline \multirow{2}{*}{$\begin{array}{l}\text { Study } \\
\text { area }\end{array}$} & \multirow{2}{*}{$\begin{array}{l}\text { Sampled } \\
\text { kebeles }\end{array}$} & \multicolumn{3}{|c|}{ Total number of HHs } & \multicolumn{3}{|c|}{ Sampled household heads } \\
\hline & & $\begin{array}{l}\text { Partici } \\
\text { pants }\end{array}$ & $\begin{array}{c}\text { Non- } \\
\text { participants }\end{array}$ & Total & $\begin{array}{l}\text { Partici } \\
\text { pants }\end{array}$ & $\begin{array}{c}\text { Non - } \\
\text { participants }\end{array}$ & Total \\
\hline \multirow{3}{*}{$\begin{array}{l}\text { Toke- } \\
\text { Kutay } \\
\text { District }\end{array}$} & $\begin{array}{l}\text { Birbirsa- } \\
\text { Duguma }\end{array}$ & 186 & 90 & 276 & 29 & 14 & 43 \\
\hline & Emela-Dawe & 223 & 63 & 286 & 34 & 10 & 44 \\
\hline & Maruf & 105 & 191 & 296 & 16 & 29 & 45 \\
\hline & & 514 & 344 & 858 & 79 & 53 & 132 \\
\hline
\end{tabular}

Source:Toke -Kutaye District Agriculture Bureau, (2016)

Primary and secondary sources of data were used. Quantitative data from primary source were collected through household survey using a semi-structured interview schedule. Qualitative data were collected through key informant interviews and focus group discussions. The secondary data were collected through a review of relevant reports of district agricultural and rural extension offices, published and unpublished sources.

\section{FINDINGS AND DISCUSSION}

\section{Factors influencing rural women participation} in agricultural extension services

To study the factors influencing rural women participation in agricultural extension services, data gathered from 132 women vegetable farmers were subjected to binary logit regression analysis.

\section{Results of Binary Logistic Regression Analysis}

The binary logit model results revealed that rural women participation in agricultural Extension Services was determined by the interaction of different demographic, socioeconomic, institutional and women related factors. The main objective of the model, in particular, is to analyze the factors that determine the probability of participation in agricultural extension services. The estimated parameter of the independent variables expected to influence rural women participation in agricultural extension services are presented in Table 2. 
Determinants of Rural Women's Participation in Agricultural Extension Services: Case of Irrigable Vegetable Production in Oromia Region, Ethiopia

The variables viz., farm experience, sex of development agent, irrigable land holding and access to credit showed significant and positive relation with participation. This indicates that any increase in any of these variables will increase the probability of women participation in agricultural extension services. Whereas time spent on domestic activities, distance from water source, sex of household headship, and mobility constraints shows significant and negative relationship with women participation. The negative relationship implies that an increment in any of these variables will reduce women participation in agricultural extension services among studied women farmers.

Table 2.

Binary Logistic regression estimates of Determinants of Rural women Participation in Agricultural extension services

\begin{tabular}{|c|l|c|c|c|c|c|l|}
\hline Sl. & \multicolumn{7}{|c|}{ VARIABLES IN THE EQUATION } \\
\cline { 2 - 8 } No & & \multicolumn{1}{|c|}{ B } & S. E & WALD & Df & SIG. & EXP( $\beta)$ \\
\hline 1 & Level of Education & -.212 & .733 & .084 & 1 & .772 & .809 \\
\hline 2 & Total Number of Dependents & -.424 & .292 & 2.113 & 1 & .146 & .654 \\
\hline 3 & Sex of The Household Head & -2.480 & .977 & 6.442 & 1 & .011 & $.084^{* *}$ \\
\hline 4 & Farm Experience & .156 & .039 & 15.606 & 1 & .000 & $1.169^{* * *}$ \\
\hline 5 & Irrigable Land Holding & .207 & .097 & 4.595 & 1 & .032 & $1.230^{* *}$ \\
\hline 6 & Total Livestok Holding & .443 & .438 & 1.022 & 1 & .312 & 1.557 \\
\hline 7 & Annual Income & .000 & .000 & 1.592 & 1 & .207 & 1.000 \\
\hline 8 & Access To Credit & 1.585 & .783 & 4.099 & 1 & .043 & $.205^{* *}$ \\
\hline 9 & Sex of Development Agents & 2.467 & .830 & 8.829 & 1 & .003 & $11.783^{* * *}$ \\
\hline 10 & Contact Wih Development Agents & 1.443 & 1.163 & 1.539 & 1 & .215 & 4.233 \\
\hline 11 & Distance From FTC & -.398 & .503 & .626 & 1 & .429 & .672 \\
\hline 12 & Access To Input & -.861 & .758 & 1.290 & 1 & .256 & .423 \\
\hline 13 & Mobility Constraint & -1.121 & .654 & 2.939 & 1 & .086 & $.326^{*}$ \\
\hline 14 & Reproductive Role & .944 & .675 & 1.953 & 1 & .162 & 2.570 \\
\hline 15 & Distance From Water Source & -.955 & .486 & 3.859 & 1 & .049 & $.385^{* *}$ \\
\hline 16 & Time Spent on Domestic Activities & -.566 & .190 & 8.835 & 1 & .003 & $.568^{* * *}$ \\
\hline 17 & Constant & 4.455 & 2.725 & 2.673 & 1 & .102 & 86.099 \\
\hline
\end{tabular}

Dependent Variable Note $^{*}, * *$ and ${ }^{* * *}$

-2Log likelihood Cox \&Snell R square
Participation in Agricultural Extension Services

$=$ Significant at 10, 5 and $1 \%$ respectively

$=75.456^{\mathrm{a}}$

$=.540$
Nagelkerke R square

Chi -square

Sign.
$=.729$ 102.380

$=.000$ 


\section{Sex of the Household Headship}

The coefficient of this variable is negative and significant at less than $5 \%$ probability level towards participation. The result indicates that, women in male- headed households were 084 times less likely to participate in agricultural extension services than women-headed households. It implies that women in male-headed households have a less probability of participation than women headed households. This could be due to the reason that women in male headed households have to get the permission from their husbands. Mostly in the maleheaded households, the head of the family takes all the responsibilities outside home and thrusts all the household works to the women.

\section{Irrigable Land holding size}

The effect of irrigable land holding size significantly influences the probability of participation. The coefficient of this variable is positive and significant at less than $5 \%$ probability level towards participation. For a unit increase in farm size, the odd of being participate in agricultural extension services significantly increases by a factor of 1.23 times. This means that households who have access to more irrigable land are more likely to participate in agricultural extension services as compared to households who have less land. This finding is in line with the finding of Marte yet al., (2013) who observed that farm size positively influenced the household heads' decision to participate in agricultural projects.

\section{Farming Experience}

Farming experience was positive and significant at less than $1 \%$ level of significance. It is consistent with the notion that farmers with longer years of experience accept and adopt the technology than farmers with low faming experience. Women with more farming experience were more likely to participate in agricultural extension services than those who haveless experience. Theresults also reveal that for one-unit increase in farming experience, the odd of being participate in agricultural extension services significantly increases by the factor of 1.169 times. Therefore, women's experience in vegetable production increases their probability of participation in agricultural extension programme. Moreover, women who have been growing vegetable for more years are more likely to value the benefits from participating in agricultural extension services. The result is also in in line with the finding of Chioma (2014) who reported that farming experience was found to be positively associated with participation. This finding is in contradiction with the finding of Rehman \& Ibrahim (2007) who indicated that farming experience had no significant effect on the farmers' access to agricultural information.

\section{Access to Credit}

Access to credit helps the farmers by easing financial constraints to purchase inputs for vegetable farming. The coefficient of access to credit is positive and significant at less than $5 \%$ probability level. As shown in Table 2, women who had better access to credit were .205 times more likely to be participate in agricultural extension services than women 
Determinants of Rural Women's Participation in Agricultural Extension Services: Case of Irrigable Vegetable Production in Oromia Region, Ethiopia

had no credit access. Women who have access to credit have a better possibility of getting farm inputs. Credit helps farmers to purchase inputs such as seeds, fertilizers etc., The result is consistent with the finding of Martey et al.,(2013) who reported that access to credit enables farmers to overcome their financial constraints associated with production and adoption of innovations.

\section{Sex of Development Agents}

The beta coefficient is positive and significant at less than $1 \%$ probability level. The results of logit model showed that those women farmers who have contact with female development agents were 11.783 times more likely to participate in agricultural extension services than those who had no contact. It implies that female extension workers are often in a better position to help female smallholder farmers in the adoption of innovations.

\section{Distance from Water source}

The coefficient of distance from water source is negative and significant at less than $5 \%$ level of significance. This variable was found to influence women participation in agricultural extension services negatively and significantly at less than $5 \%$ significance level. Longer the distance from water source, lesser would be, the initiative of women to participate in extension services. The possible justification could be households who are farther to the water source incur much cost to have access to irrigation. So, they can't follow up the farm activity closely and frequently and may not get a better yield; therefore, they delay in deciding to participate in agricultural extension services. Conversely, shorter the distance from the a water source, higher the probability of participating in agricultural extension services due to the fact that the opportunity cost of the time lost in travelling to and from an irrigation-farm for households located a short distance from water source would be much lower than households located much farther.

Besides, households located near water sources enjoy the lower transaction cost, and also are likely to have a better awareness of the associated agricultural technologies due to their proximity. The odds ratio also revealed that for one kilometer decrease in distance from residence to water source the odds of being able to participate in agricultural extension services significantly increases by the factor of .385 units while other variables are kept constant.

\section{Time spent on domestic activities}

As expected, the beta coefficient for time spent on domestic activities is negative and significant at less than $1 \%$ probability level. The relationship is negative, which means that the women who spend more time in domestic activities, are less likely to participate as compared to women who have leisure time. The result indicates that as time spent on domestic activities increases by one hour, the probability of women participation in agricultural extension services decreases by a factor of .568. The possible explanation for this result is that respondents who spent more time on domestic activities had less probability to participate in agricultural extension services. 
Time-use surveys across a wide range of countries estimate that women spent 85-90 per cent of the time on childcare, water $\&$ food collection, cooking and other care activities (FAO 2011b; Flavia, Josefine \& Sophia, 2015).

\section{Mobility Constraints}

The coefficient of mobility constraints is negative and significant at less than $10 \%$ level of probability. As mobility constraints decrease by one unit the odd ratio increases by the factor of .326 . Those women who have no mobility constraints could participate in any association, development intervention, etc. Time and mobility constraints may prevent women from accessing public extension and formal agricultural information services. In such situations, women need to rely extensively on their female social net-works to learn about new agricultural technologies.

However, the remaining eight explanatory variables were found to have no significant influence on the probability of participation in agricultural extension services. The non- significant variables were education, number of dependents, livestock holding, annual income, contact with development agents, distance from FTC, access to input and reproductive role. These variables, therefore did not determine their participation in this study.

\section{CONCLUSION}

The results of the Binary Logistic regression model estimate indicate that out of the 16 explanatory variables included in the model, the coefficients of the eight explanatory variables were found to be significant indicating that any change in this variable will substantially influence on the probability of being a participant in agricultural extension services.

The study indicates that increase in variables viz., farming experience, sex of development agent,irrigable land holding size and access to credit will increase the probability of women participation in agricultural extension services. Whereas time spent on domestic activities, distance from water source, mobility constraints and sex of household headshipshows significant and negative relationship with women participation. The negative relationship implies that an increment in any of these variables will reduce women participation in agricultural extension services among the women farmers.

Majority of the respondents have no contact with female agricultural extension workers.This implies that the linkage between the women farmers and the Development Agents (DAs) is very weak. Therefore, to improve the rural women's participation, assigning and allocating appropriate number of female agricultural extension workers (DAs) in the rural kebele associations (KAs) is recommended. The study revealed that distance from water sources has its own contribution for women participation in agricultural extension services; Therefore, the Zonal and Woreda (District) governmental bodies have to provide subsidies and incentives to women farmers to adopt water conservation practices. In addition, the regional water enterprise has to make provision to pump 
Determinants of Rural Women's Participation in Agricultural Extension Services: Case of Irrigable Vegetable Production in Oromia Region, Ethiopia

underground water for small-scale irrigation. Participation in agricultural extension services could further increase women's workload. Hence all stakeholders should give great attention and priority to reduce the workload of women by providing access to labour saving household technologies.

\section{REFERENCES}

Chioma U. N. (2014). Socio-Economic Factors Influencing Farmers' Participation in Community- Based Programme in Abia and Cross River States of Nigeria.Journal of Agricultural Extension, 18(1), 48-61. Retrieved from http://dx.doi.org/10.4314/ jae.v18i1.5

Cohen, M. J. \& Lemma, M. (2011). Agricultural Extension Services and Gender Equality: An Institutional Analysis of Four Districts in Ethiopia. IFPRI Discussion Paper 01094, Development Strategy and Governance Division, IFPRI, Washington, DC. Retrieved from http://www.ifpri.org/publication/ agricultural-extension-services-andgender-equality-0

Manfre C., Deborah R., Andrea A., Gale S., Kathleen C., \& Mercy A. (2013). Reducing the gender gap in agricultural extension and advisory services: How to find the Best Fit for men and women farmers. MEAS discussion paper series on Good Practices and Best Fit approaches in extension and advisory service provision, USAID. Retrieved from http://meas.illinois.edu/ wp-content/uploads/2015/04/Manfreet-al-2013-Gender-and-Extension-MEASDiscussion-Paper.pdf

Martey E., Wiredu A. N., Asante B.O., Annin K., Dogbe W., Attoh C., \& Al-Hassan R. M.(2013). Factors influencing participation in rice development projects: the case of smallholder rice farmers in Northern Ghana. International Journal of Development and Economic Sustainability, 1 (2),13-27. Retrieved from https://www.researchgate. net/publication/237080930_factors influencing_participation_in_rice_ development_projects_the_case_of smallholder_rice_farmers_in_northern_ ghana

TKADO.(2016). Toke -Kutay Agricultural Development Office Report. Toke -Kutay district, Oromia, Ethiopia.

TKADOI.(2016). Toke -Kutay Agricultural Development Office Irrigation Report. Toke Kutay district, Oromia, Ethiopia.

World Bank. (2010). Gender and governance in rural Service: Insight from India, Ghana, and Ethiopia. Agriculture and rural development series, World Bank, Washington, D.C. ISBN: 978-0-8213-7658-4, elSBN: 978-0-82138156-4, DOI: 10.1596/978-0-8213-7658-4 